\title{
The Use of Local Lore Materials at Lessons of History of Ukraine in Secondary General Education Institutions
}

\author{
Dmytro Nefyodov \\ Doctor of Historical Sciences \\ Provisional Head of the Department of History, \\ Mykolaiv V.O. Sukhomlynskyi National University \\ nefyodovdv@gmail.com
}

\begin{abstract}
The article studies the peculiarities of the use of local lore materials at history lessons. The author concludes that the use of local lore materials at history lessons is one of the means of enhancing students' cognitive activity and encouraging research. Knowledge of local lore studies enriches program material, makes it clearer, more logical and convincing and, of course, helps to improve the quality of knowledge. In the process of study of History of Ukraine, focusing on specific facts, events, processes and phenomena of local lore contributes to students' awareness of the historical basis of the regional-cultural, ethnographic, religious, social and economic diversity of Ukraine within a single national history. Understanding of regional peculiarities (historical-geographical, ethnographic, cultural, religious, mental) as a result of a complex of events, processes and phenomena of the historical development of the Ukrainian territory is a significant factor in shaping the social consciousness of the young generation, which has to understand the state and national unity of Ukraine through regional variety of all manifestations of life of the Ukrainian nation.

Keywords: History of Ukraine, local lore studies, methodology.
\end{abstract}

The modern development of the Ukrainian state, the emergence of civil society, national-cultural revival and the acceleration of the integration processes of Ukraine into the European and world community significantly change the place and role of history as a basic school subject, which is responsible for solving the important tasks of modern education: providing conditions for adaptation and self-realization of young people in the changing modern world, acquisition of important life competencies and guidelines that promote personal development, formation of national consciousness and civic position.

Since Ukraine's independence, historical education has dramatically changed of all school subjects. The current stage of social development requires the study of the national history, particularly through the prism of the peculiarities of regions' history. A person is brought up in a socio-cultural environment that has been formed for centuries. Therefore, the study of local lore is of particular importance in forming a sense of national identity, democracy and tolerance, respect for the historical trajectory of native and other peoples. Today local lore studies is one of the basic elements of historical education, one of the most important branches of history at school, an important means of connecting school with life; 
one of the sources of enriching students with knowledge on the history of their native land, a means of fostering love for it and formation of civic concepts and qualities.

School local lore studies is a component of historical education, which is based on the methodological foundations of the historical and pedagogical scientific fields and has its own methodological specificity. An important condition for the development of local lore studies is, first of all, the contemporary socio-political changes that take place in Ukraine and in the world. The local lore materials, enriched with tradition, allow students to notice the cultural difference of their own environment and at the same time to trace the specifics of individual territories as closed regions or spaces. Therefore, one of the urgent issues of further transformation of the content of school historical education today is the establishment of the optimal correlation between national and regional history, particularly within the subject namely History of Ukraine.

Increasing attention to local lore issues in the classroom gives students the opportunity to be more aware of the history of not only their native land, but also of other regions of Ukraine, to awaken the desire to cooperate with people from other regions, to realize the unity of the country in the conditions of regional differences' existence.

Before using local lore materials in the educational process, it is necessary to determine their importance and place in the historical science. So, when selecting local lore materials, you should first pay attention to whether they:

- have important educational value;

- are closely related to the program of History of Ukraine;

- contribute to a deep understanding of the general patterns of the historical process and features of region's historical development;

- have novelty and relevance;

- reflect the unity of civilizational and cultural approaches in the process of their study;

- take into account the differentiated approach to students.

In addition to teaching at higher educational institution of the IV accreditation level, the author of this article also teaches at the Lyceum, which is an upper secondary education institution. Faculty members of the Department of History of Mykolaiv V.O. Sukhomlynskyi National University, including the author of this article, in 2015 created a unique textbook "History of Native Land: Mykolaiv Oblast" [1] on the pages of which the history of the 
Mykolaiv oblast from ancient times to the present is revealed. The authors, basing on archival documents and materials, demonstrated the emergence of life in the region. In addition to historical events, they also presented such issues as national minorities, the culture of the region, prominent figures and more. The textbook was received by all secondary general education institutions in the Mykolaiv oblast, which in turn made it possible to study the local lore more actively at the lessons of History of Ukraine.

In our teaching activities in the Lyceum at lessons of History of Ukraine, we actively use local lore materials. Thus, using the textbook by O. Hisem and O. Martyniuk [2] in the 9th grade, at the end of each unit, we devote one lesson to the topic "Our land" analyzing the relevant historical period.

In the history of each state we usually consider its components: history of lands, territories, provinces, regions, etc. To link local historical material to general history material we use the following techniques:

- form a comprehensive knowledge of both the history of the region and the history of the country;

- determine the general and special features of events, phenomena of universal and local significance;

- set synchronization of events from the history of the country and the local areas;

- identify important historical events of local importance that are not mentioned in the context of general history for some reason;

- carry out the study of the local history with the general history synchronously or in its context;

- try to focus students' attention on the facts of local history, because they are closer and more real to them.

We defined the following main methodological conditions for successful study of local lore issues in the course of History of Ukraine:

- giving a special attention by a teacher to the development of the content of such concepts as "region" and "native land" with the simultaneous acquisition of the ability to specify the relevant events and processes in time and space;

- teaching local lore materials in the course of national history from the standpoint of multiperspectivity and multiplicity; 
- highlighting appropriate tasks and questions for students aimed at developing their historical competence at the lessons of local lore-oriented educational content;

- providing active participation of students at the lessons of local lore studies by means of interactive teaching methods.

The use of local lore materials at history lessons is one of the means of enhancing students' cognitive activity, encouraging research. Knowledge of local lore studies enriches program material, makes it clearer, more logical and convincing and, of course, helps to improve the quality of knowledge.

Thus, in the process of study of History of Ukraine, focusing on specific facts, events, processes and phenomena of local lore contributes to students' awareness of the historical basis of regional cultural, ethnographic, religious, social, economic diversity of Ukraine within a single national history. Understanding of regional peculiarities (historical-geographical, ethnographic, cultural, religious, mental) as a result of a complex of events, processes and phenomena of the historical development of the Ukrainian territory is a significant factor in shaping the social consciousness of the young generation, which has to understand the national unity of Ukraine through regional variety of manifestations of life of the Ukrainian nation.

The completed research does not exhaust all aspects of the problem, in particular, approaches to the implementation of the content of local lore studies in school textbooks in general in Ukraine and the professional training of history teachers to teaching local lore studies in the course of History of Ukraine require further studies.

\section{References}

1. Istoriia ridnoho kraiu : Mykolaivshchyna : navchalnyi posibnyk [History of Native Land: Mykolaiv Oblast: textbook] / M. M. Shytiuk (ker. avt. kol.), O. O. Bakovetska, N. M. Buhlaitain. - Mykolaiv : Ilion, 2015. - 628 s.

2. Hisem O. V., Martyniuk O. O. Istoriia Ukrainy : pidruchnyk dlia 9 klasu zahalnoosvitnikh navchalnykh zakladiv [History of Ukraine : textbook for the 9th grade students of secondary general education institutions]. - Kharkiv: Ranok, 2017. - 288 s. 